\title{
Distribution of Plasmodiophora bicaudata, a parasitic fungus on small Zostera species
}

\author{
C. den Hartog \\ Laboratory of Aquatic Ecology, Catholic University, Toernooiveld, 6525 ED Nijmegen, The Netherlands
}

\begin{abstract}
The slimemold Plasmodiophora bicaudata J. Feldmann, described as a specific parasite of the seagrass Zostera noltii Hornemann, has been found on several other species of Zostera subgen. Zosterella. It causes characteristic galls by preventing the elongation of the internodes of the host; these become strongly swollen. Consequently, infected plants have a bulbous base and a very tufted appearance. The area of distribution of the parasite probably coincides with that of Zostera subgen. Zosterella. In spite of this it is a rare species, the occurrence of which is at present still unpredictable.
\end{abstract}

Plasmodiophora bicaudata J. Feldmann is a parasitic fungus that forms very characteristic galls on Zostera noltii Hornemann. The species was described from Tanoudert, Mauretania (J. Feldmann 1940), and was also found in Etang de Salses, France (G. Feldmann 1954, 1956). Although the species has been incorporated in handbooks (Karling 1942, 1968, Johnson \& Sparrow 1961), no other information has been published, except for a record from The Netherlands (den Hartog \& Polderman 1973). In this paper all available information on the species is presented.

Plasmodiophora bicaudata forms ovoid or slightly spindle-shaped ( 6 to $7 \mu \mathrm{m}$ by 3 to $4 \mu \mathrm{m}$ ), thin-walled, pale or bright yellow resting spores, with a fine filiform appendage at one or at both ends (best visible under phase contrast). The germination of these spores is still unknown. The plasmodia are large, and completely fill up the cells of the host. The effect on the host has been described by J. Feldmann (1940) and G. Feldmann (1956). Hypertrophy of the host cells is caused by cell enlargement, since division of infected and adjacent healthy cells has not been observed. The parasite is confined to the cortical and epidermal cells, and does not affect the vascular bundles; consequently leaf growth is not or only slightly affected. So far, no infected shoots have been found with inflorescences.

The gall formation produced by the parasite on Zostera noltii is very conspicuous. The internodes seem unable to stretch, and swell up. As a consequence infected shoots have a more or less bulbous base. In the case of heavy infection a number of these bulbous bases are closely adjacent, giving the host plant a densely tufted appearance, and the habit becomes slightly reminiscent of that of Isoetes. The roots of the diseased shoots are often badly developed. In the herbarium the diseased parts of the plant blacken.

The galls can be easily recognized in herbarium material. Therefore, a large number of sheets of Zostera noltii, but also of other Zostera species, were checked for the presence of the parasite. From specimens showing the gall formations small samples were taken for microscopical examination; only when the spores with their characteristic filiform appendages were found was the material assigned to Plasmodiophora bicaudata.

The herbarium study of Zostera noltii showed that galls collected in The Netherlands, Germany and Sweden were not recognized by the collectors as an aberration. It also became clear that Plasmodiophora bicaudata is not confined to $Z$. noltii, it could be positively identified in $Z$. capensis Setchell from South Africa, Z. muelleri Irmisch ex Ascherson from Victoria (Australia) and Z. japonica Ascherson \& Graebner from British Columbia (Canada). Therefore, it seems likely that the parasite is characteristic of species of Zostera subgen. Zosterella. In species of Zostera subgen. Zosterella, to which $Z$. marina $\mathrm{L}$. belongs, no galls were found, although more than 1000 specimens were checked.

In Zostera capricorni Aschers. from New South Wales (Australia), the characteristic gall formation was found, but no appendages were visible on the spores. This may perhaps mean that the spores were not fully developed, but another possibility is that this was not Plasmodiophora bicaudata, but rather a closely allied species. The diseased plant was found in a small popula- 


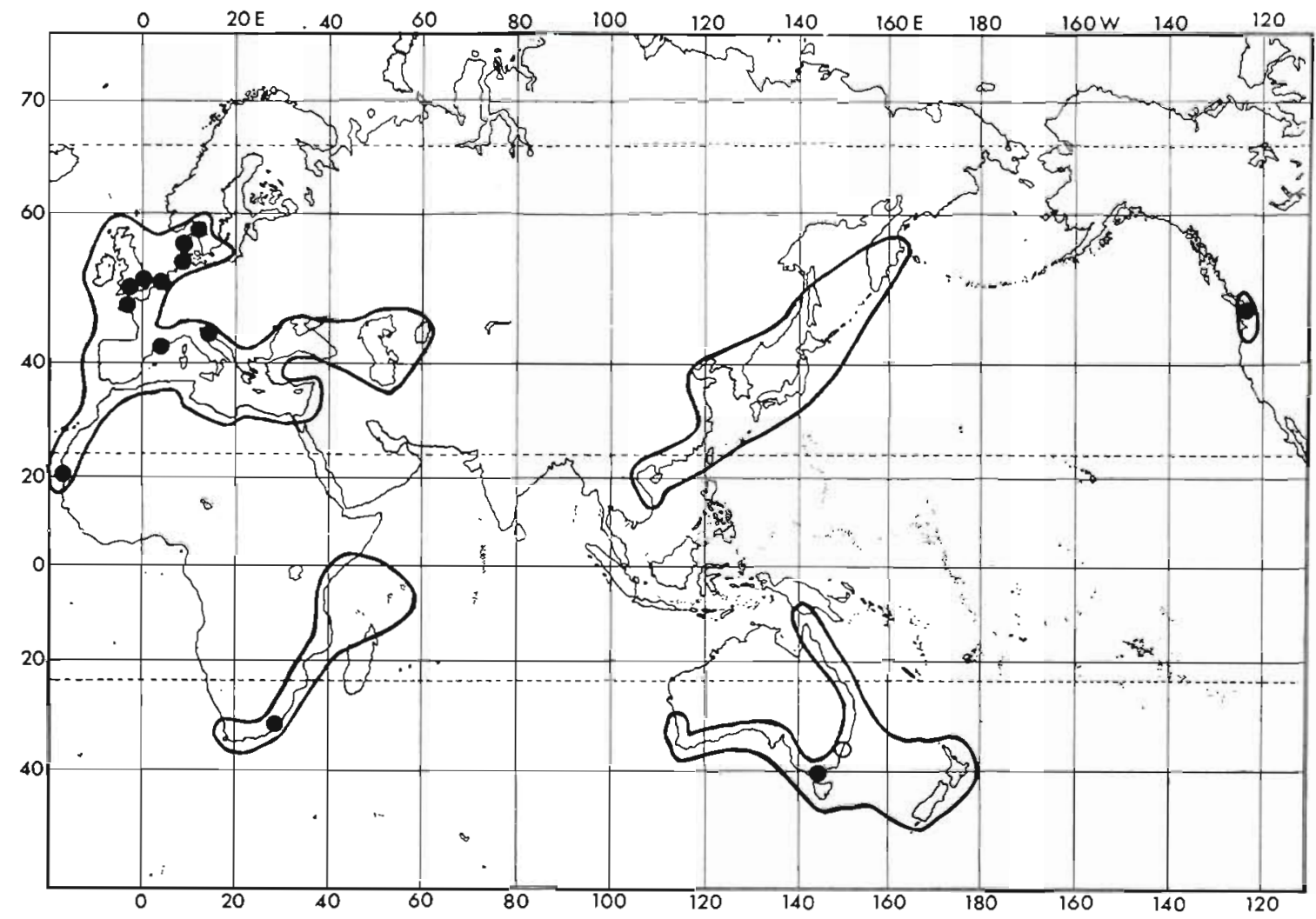

Fig. 1. Plasmodiophora bicaudata. Geographical distribution. The area of distribution of Zostera subgen. Zosterella has been delineated. Open circle refers to the specimens from Sydney, the spores of which do not have the filiform appendages

tion, characterized by very narrow leaves of at most $2 \mathrm{~mm}$ wide; in fact they were the smallest plants of $Z$. capricorni I have ever seen. Further research on Australian material is therefore recommended.

The geographical distribution of Plasmodiophora bicaudata is illustrated in Fig. 1 and details of the localities are listed in Table 1 . I have personally seen all material, except for the type specimen from Mauretania. The number of records of $P$. bicaudata is low if one considers the area of its potential geographic distribution. Generally one quite accidentally finds one or a few infected plants. Even, if one searches particularly for densely tufted Zostera specimens, the number of galls found remains unpredictable. The parasite is thus rare, in spite of its wide distribution.

The few existing data also show that the parasite is persistent in certain localities. It is evident from the herbarium labels that it was found at Husum (North Sea coast of F.R. Germany) in 1843, 1844 and 1845. G. Feldmann (1956) collected the species repeatedly at Etang de Salses (France) in May, June, July and August of 1954 and 1955. Further, it is noteworthy that the specimen I collected in the Zandkreek (The Netherlands) in July 1987 was in exactly the same area where Van den Bosch found it in 1841. However, nothing is known about the way Plasmodiophora bicaudata maintains itself within a Zostera bed. As $Z$. noltii is a perennial, hibernating with its rhizomes, it is most likely that the parasite survives in one or another form in the rhizomes. It is also not known how the transfer from plant to plant takes place, nor the route of infection. Possibly dispersal over larger distances may be effected by floating infected Zostera plants. Due to the poor development of the roots of infected Zostera plants, uprooting takes place relatively easily. In Rovinj (Yugoslavia) I found an infected plant floating on the surface. At Exmouth (SW England) I collected an infected specimen washed up on the beach, while an hour spent searching in the $Z$. noltii bed nearby yielded only 3 infected plants.

The record of Plasmodiophora bicaudata on Zostera japonica near Vancouver (Canada) is most remarkable. $Z$. japonica settled here very recently (Harrison \& Bigley 1982); in 1976 it was first found in the locality (Harrison 1982) where in 1985 P. bicaudata was discovered. For this reason it is very probable that the parasite also occurs in East Asia, although no $Z$. japonica with the disease has been recorded so far from there.

Acknowledgement. The figure was prepared at the Illustration department of the Faculty of Sciences, Catholic University, Nijmegen 
Table 1 Plasmodiophora bicaudata. Survey of herbarium material

\begin{tabular}{|c|c|}
\hline Country & Locality details \\
\hline France & $\begin{array}{l}\text { - St. Efflam, Côtes du Nord, } 21 \text { Jul 1972, C. den Hartog, on Zostera noltii, extensive intertidal sand flat } \\
\text { (L) } \\
\text { - Etang de Salses, Pyrenees Orientales, } 17 \text { May 1955, J. Feldmann 9121, on Zostera noltii (PBVM) }\end{array}$ \\
\hline The Netherlands & $\begin{array}{l}\text { - Zeeland, salt-marshes along the Oosterschelde, Sep 1841, R. van den Bosch, on Zostera noltii (L) } \\
\text { - Salt marshes along the Zandkreek, eastern part, } 15 \mathrm{Sep} 1841 \text {, R. van den Bosch, on Zostera noltii (L) } \\
\text { - Mudflats of eastern part of the Zandkreek, 22 Jul 1987, C. den Hartog, on Zostera noltii (L) } \\
\text { - Mudflat in the Eendracht, Tholen, } 8 \text { Aug 1951, S. E. de Jongh, J. G. Sloff \& Th. J. Reichgelt, 19708, on } \\
\text { Zostera noltii (L) } \\
\text { - Island of Terschelling, Friesland, near the Wierschuur, } 30 \mathrm{Sep} \mathrm{1972,} \mathrm{P.} \mathrm{J.} \mathrm{G.} \mathrm{Polderman,} \mathrm{on} \mathrm{Zostera} \\
\text { noltii, intertidal sandflat (L) }\end{array}$ \\
\hline F. R. Germany & $\begin{array}{l}\text { - Husum, Schleswig-Holstein, Sep 1844, F. von Müller, on Zostera noltii (MEL 2946) } \\
\text { - Husum, } 1843 \text { and 1845, F. von Müller, on Zostera noltii (MEL 2947) }\end{array}$ \\
\hline Sweden & - Marstrand Koon, Bohuslan, 26 Jul 1893, Carl Stennann, on Zostera noltii (US) \\
\hline England & $\begin{array}{l}\text { - Whitstable, Kent, in front of Seasalter, } 19 \text { Sep 1988, C. den Hartog, on Zostera noltii (L, BM) } \\
\text { - Exe Estuary between Exmouth and Lympstone, Devon, } 23 \text { Sep 1988, C. den Hartog, on Zostera noltii, } \\
\text { growing in the sandiest part of the Zostera bed; also one diseased specimen washed up on the beach at } \\
\text { Exmouth (L) }\end{array}$ \\
\hline Yugoslavia & $\begin{array}{l}\text { - Rovinj, Istria, at the interior end of the Limskikanal; ca } 15 \mathrm{~km} \text { Nof Rovinj, } 2 \text { Oct 1971, C. den Hartog, on } \\
\text { Zostera noltii (L) } \\
\text { - Otok Katarina, opposite Rovinj, } 2 \text { Oct 1971, C. den Hartog, on Zostera noltii, floating in the sea (L) }\end{array}$ \\
\hline Mauretania & - Tanoudert, 25 Apr 1938, M. Murat, on Zostera noltii (TYPE, P) \\
\hline South Africa & $\begin{array}{l}\text { - Knysna district, Cape Province, between Steenbok Island and Woodbourne, } 17 \text { Jan 1933, A. V Duthie, } \\
\text { on Zostera capensis (UC) }\end{array}$ \\
\hline Australia & $\begin{array}{l}\text { - Queenscliff, Victoria, 1906, H. B. Williamson, on Zostera muelleri (MEL 3733) } \\
\text { - Sydney, New South Wales, Port Jackson, Woolloomooloo Bay, on sand in the intertidal belt, } 2 \text { Dec } 1967, \\
\text { C. den Hartog } 1102 \text {, on very narrow-leaved specimens of Zostera capricorni, spores without the } 2 \\
\text { appendages and therefore identification uncertain (L) }\end{array}$ \\
\hline $\begin{array}{l}\text { Canada } \\
\text { a Codes for the he }\end{array}$ & $\begin{array}{l}\text { - Vancouver, British Columbia, southern Roberts Bank, foreshore of the delta of the Fraser River, } \\
\text { intercauseway area (see Harrison, 1982), } 22 \text { Jul 1985, C. den Hartog \& P. G. Harrison, on Zostera } \\
\text { japonica (L). } \\
\text { aria where the material is kept are indicated in brackets }\end{array}$ \\
\hline
\end{tabular}

\section{LITERATURE CITED}

den Hartog, C., Polderman, P. J. G. (1973). Plasmodiophora bicaudata, een parasiet op Zostera noltii. Gorteria 6: 121-123 (Dutch)

Feldmann, G. (1954). La végétation de l'Etang de Salses (rive sud). Vie Milieu 4: 685-700

Feldmann, G. (1956). Développement d'une Plasmodiophorale marine: Plasmodiophora bicaudata J. Feldm., parasite du Zostera nana Roth. Revue. gén. Bot. 63: $390-420$

Feldmann, J. (1940). Une nouvelle espèce de Plasmodiophora (P. bicaudata) parasite du Zostera nana. Bull. Soc. Hist. nat. Afr. Nord 31: 171-177
Harrison, P. G. (1982). Seasonal and year-to-year variations in mixed intertidal populations of Zostera japonica Aschers. \& Graebn. and Ruppia maritima L.s.l. Aquat. Bot. 14: $357-371$

Harrison, P. G., Bigley, R. E. (1982). The recent introduction of the seagrass Zostera japonica Aschers. and Graebn. to the Pacific coast of North America. Can. J. Fish. Aquat. Sci. 39: $1642-1648$

Johnson, T W. Jr., Sparrow, F. K. Jr (1961). Fungi in oceans and estuaries, J. Cramer, Weinheim

Karling, J. S. (1942). The Plasmodiophorales. Published by the author, New York

Karling, J. S. (1968). The Plasmodiophorales, 2nd edn. Hafner Publ. Co. New York 